\title{
Enterprise-oriented Practical Teaching Model of Art and Design in Universities
}

\author{
Fang Li \\ School of Fine Arts \\ Chengdu Normal University \\ Chengdu, China 611130
}

\begin{abstract}
This paper puts forward some thinking on what enterprise-oriented practical teaching model is, why and how to construct it, and hopes to achieve the purpose of excellent applied design talent training through the practical application of enterprise-oriented practical teaching model.
\end{abstract}

Keywords - art and design major; enterprise-oriented practical teaching; teaching management

\section{INTRODUCTION}

In the digital era, the deep integration of informatization and industrialization and the rapid development of cultural creative industry and design service industry require higher education to cultivate new type applied high quality design talents with theory and practice, high comprehensive cultural quality and teamwork spirit for production and services in the modernized society. It proposes in the Outline of the National Medium and Long Term Educational Reform and Development (2010 to 2020) that: The improvement of social economic standard requires innovative elites as well as practitioners with technical skills. The development of higher education requires the innovation and application of advanced technology and the cultivation of high quality applied talents for the front line of modernized production. [1] According to the requirements of social development for applied talents, universities at home establish simulated training rooms in companies or plants in order to improve students' manipulative ability. However, the enterprise-oriented practical teaching that brings real projects in enterprises in classroom teaching of art and design and carries out "two-in-one" of practical teaching management with enterprise operation remains to be perfected.

\section{ENTERPRISE-ORIENTED PRACTICAL TEACHING MODEL FOR ART AND DESIGN MAJOR}

Enterprise-oriented practical teaching model for art and design major refers to the talent training program that fully considers strengths and weaknesses of school type, level, discipline, characteristics and service area and integrates professional practical teaching system in art and design major. It pays attention to the implementation of talent training programs and teaching plan, bases on practical contents of talent training program to establish practical teaching management office; establish registered company based on the practical teaching management office to promote effective implementation of enterprise-oriented practical teaching model and realize "two-in-one" of practical teaching management office and registered company. The practical teaching management office is administrative department and corporate behavior.

\section{SIGNIFICANCE OF CONSTRUCTING ENTERPRISE- ORIENTED PRACTICAL TEACHING PATTERN FOR ART AND DESIGN MAJOR}

\section{A. Increase the Conversion Rate of Achievements in Scientific Research}

Practical teaching management office (registered company) bases on art and design major in universities. With talents of scientific research and long-term technology accumulation, as a new type modern enterprise system, it converts achievements in scientific research into economic benefits, improves resource utilization rate and shares human resource. Its development can break the limitation of traditional school system and increase the conversion rate of achievements in scientific research. Practical teaching management office (registered company) becomes good carrier to transfer knowledge and convert achievements in scientific research. At present, professional companies established by universities such as Beijing Institute of Technology, Central South University and Zhejiang University have made achievements and become forerunners in exploring the combination of production, learning, scientific research and practical application at home. [2]

\section{B. Improve Cultivation Quality of Practical Talents}

In the implementation of "two-in-one" teaching model related to practical teaching management and company, we should value students' subjectivity and experience and "the integration of teaching, learning and doing". The teaching model that students attend class passively is changed to let them grow in all-round practical training and improve their learning effect and professional quality as well as train their teamwork spirit. It makes up for the defects of traditional talent training pattern and lets students face and adapt to the society, in order to improve the talent training quality.

\section{Improve the Construction Level of Art and Design}

The "two-in-one" teaching model of practical teaching management and company avails teaching reform in school and improves the construction level of art and design major. 
Practical teaching management office (registered company) can bring projects in classroom to integrate practical projects with classroom teaching, avails the modification of talent training programs according to social and market demands. Characteristic specialty and brand specialty can form in the construction of practical course system to promote teaching construction. Meanwhile, it expands the social influence of schools and students' employment channel and conveys high level practical talents for the society.

\section{CONSTRUCTION OF ENTERPRISE-ORIENTED PRACTICAL TEACHING PATTERN FOR ART AND DESIGN MAJOR}

\section{A. Establish Organizations That Conform to Market Operation and Teaching Development}

In order to guarantee the normal operation of teaching in art and design major and the legitimate interests of schools and students, organizations with clear division of work and authoritative and representative members should be established. Leaders in schools form leading group that is responsible for the development planning of "two-in-one" of practical teaching and company project, draft of guidelines, signing of project agreement and approval of estimated costs. The practical teaching management office (registered company) should assign person to formulate practical teaching links and management system, arrange teaching time with integration of courses and projects, and deal with problems in practical teaching inspection. They should summarize information of practice projects and combine market dynamics and customer demands with teaching of courses and projects as well as investigate and survey the quality of students' practical ability. Professional teachers formulate operation schemes with combination of projects and teaching and stipulate the progress of project implementation. Meanwhile, student counselors coordinate and deal with daily affairs in the integration of company projects and teaching contents.

\section{B. Make Clear the Rights and Obligations of Schools, Practical Teaching Management Office (Registered Company) and Teachers}

Company project is the required practical link of course. Schools are responsible to provide safe working conditions for teachers and students. As learners and workers in the project, students are protected to avoid accident risk. Teaching administrators of practical teaching management office (registered company) arrange instructors according to specific contents of projects, supervise and guide course contents and carry out preparation and student management with integration of projects and teaching, in order to influence behaviors of students and other people who participate in the projects. Instructors guide students in knowledge learning and ability training with integration of projects and course according to the requirements. After completing the project with qualified results, students can receive credit and finish school smoothly.

\section{Train and Employ Double-Professionally-Titled and Practical Teaching Talents}

Most importantly, schools found company to cultivate and bring in practical teaching talents namely double- professionally-titled talents. Schools can use and integrate teaching resources, organize teachers to regularly visit enterprises or participate in training organized by enterprises, learn the newest idea and experience in production management to improve teachers' ability in project implementation and practical teaching. In teaching management, the cultivation of double-professionally-titled teachers is divided into three stages. In the first stage, teachers of specialized courses or professional basic course are required to attend training as visiting engineers in enterprises for more than half a year to understand operation specification and requirements of enterprises. In the second stage, train teachers' quality with double qualifications to make them able to teach theories of courses and practical cases of enterprises. In the third stage, attentions are paid to the structure of doubleprofessionally-titled teachers. On one hand, train teachers' quality with double qualifications, namely the ability of theoretical teaching, the ability to guide students in practical training and the ability to undertake technical improvement projects of companies and enterprises; on the other hand, invite technicians in enterprises to serve as practice instructors and integrate in the teaching team. Engineers from companies and enterprises will give more practical experience such as how to better combine projects with course contents to produce real benefits.

\section{Optimize the Teaching Implementation System of Art and Design Courses}

Company projects are brought in classroom teaching of design courses to improve the application of design discipline. Set teaching objectives according to company operation and teach through implementation of projects according to the teamwork mechanism of practice projects. According to the project undertaken by practical teaching management office (registered company), different classes of different majors establish project team responsibility system centered on company projects: teachers and monitors carry out strategic deployment in project production; commissaries in charge of studies are responsible for operation of course learning and strategy adjustment; league branch secretaries are responsible for performance assessment in the project. Practical teaching management office (registered company) sets staged operation objectives of the project and mobilize team members of each project to complete the course task required by the teaching objectives. If a team member fails to achieve the goal, the team is regarded as quit the competitive tender of company projects. After teams complete the project, customers and practical teaching management office (registered company) list desirable schemes or achievements of project design as contract awarded projects. After economic benefits are produced, rewards will be given to teachers and students in proportion in order to stimulate students to better realize the operation of company projects.

\section{E. Improve the Quality Monitoring System of Enterprise- Oriented Practical Teaching Model of Design}

In order to improve the work efficiency of practical teaching management office (registered company), quality monitoring system related to enterprise-oriented practical teaching model should be improved. On one hand, construct 
diversified evaluation mechanism of "double-professionallytitled" teachers. Colleges, corporations and students evaluate teachers according to completion of teaching contents and projects. On the other hand, formative evaluation and summative assessment of teaching quality are carried out by teachers and corporations. Formative evaluation consists of students' learning attitude, learning method, learning effect and problem solving method and serves as usual performance that accounts for 30 percent of the total results; summative assessment means teachers and person in charge of company mark according to effects of project completion. The average score is taken as the result of summative assessment and accounts for 70 percent of the total results.

\section{CONCLUSION}

In conclusion, the establishment of enterprise-oriented practical teaching model, the introduction of company projects to classroom teaching and the implementation of "two-in-one" of practical teaching management and company operation make students roundly understand and grasp commercial operation mechanism in the market, improve their social practice ability and the practical teaching quality of schools. Effective implementation of enterprise-oriented practical teaching model through teaching management challenges our school-running idea, the management structure and system of schools as well as talent training model and methods. It is a long-term process to construct applied practical teaching system, promote the transformation of local colleges into applied colleges and build applied technical universities with Chinese characteristics. Difficulties and challenges as well as opportunities coexist. Governments at all levels, universities, corporations and all sectors of society are required to reach a consensus to seize opportunities and meet challenges with bigger courage and determination. [3]

\section{REFERENCES}

[1] Outline of the National Medium and Long Term Educational Reform and Development $(2010$ to 2020) [DB/OL].
[ http://www.china.com.cn/policy/txt/201003/01/content_19492625_3.htm, 2010-03-01/2015-03-26

[2] He Haiyan, Kang Xiaowei, Zhang Meng. Innovation System of Combination in Production, Learning, Scientific Research and Practical Application in Universities and Disciplinary Enterprise Development [A], the 12th Parallel Sessions of the 14th Annual Meeting of Chinese Association for Science and Technology: Collected Papers of Promoting Enterprise Innovation and the Development of Characteristic Industrial Parks through Combination of Government, Production, Learning, Scientific Research and Practical Application [C], 2012: 1-5

[3] 178 Universities. Zhumadian Consensus [N], China Education Daily, Apr.28, 2014 (01) 